\title{
Que jamás la sangre derramada sirva para florecer partidos políticos. El nacimiento de FET y de las JONS en Ourense ${ }^{1}$
}

\author{
Julio Prada Rodríguez
}

\begin{abstract}
RESUMEN
ABSTRACT:

En el presente trabajo se estudia el proceso de unificación de las milicias

en la retaguardia ourensana, ofreciendo algunas claves explicativas del mismo desde la óptica regional. La utilización de documentación procedente de fuentes militares $y$ policiales, el archivo privado del máximo dirigente japista y la prensa falangista y católica provincial permiten descubrir la multiplicidad de intereses en juego en torno a la unificación y las discrepancias internas surgidas frente a la unánime conciliación de voluntades esgrimida por el régimen.

In this paper, the author studies the process of FET $y$ de las JONS gestation in the Ourense rearguard. The use of privates achives to JAP leader and other primary sources allows us to find the internal struggles hidden by the official propaganda.

KEY WORDS

Militias. Falange. JAP.

PALABRAS CLAVE

Milicias. Falange. JAP. FET y de las JONS. Franquismo.

Este trabajo se integra en el Proyecto de Investigación Representación e poder político na Galicia Contemporánea, PGIDT00PXI38201PR del que es director el prof. Jesús de Juana. Realizamos una primera aproximación al tema en la comunicación "Ya somos todos uno". La unificación de las milicias en la retaguardia franquista: el caso ourensano", presentada al Segon Congrés Recerques, Enfrontaments civils: postguerres i reconstruccions.
\end{abstract}




\section{LOS ANTECEDENTES DE LA UNIFICACIÓN}

Varios son los factores que la historiografía coincide en señalar para explicar la voluntad unificadora de Franco. Entre ellos el fracasado intento de la toma de Madrid y las perspectivas de una guerra larga, así como el criterio de influyentes aliados, tanto en España como en el extranjero, partidarios de articular política y no sólo militarmente la lucha contra la República poniendo al servicio del dictador la criatura resultante; algunos, como Nicolás Franco, José Ibáñez Martín, Moreno Torres, el conde de Mayalde, Arrarás o el cura Ignacio Menéndez-Reigada aún tenían muy presente el referente de la Unión Patriótica, pero no se deseaba repetir el mismo error de crear de la nada un partido «franquista». No menos importantes fueron los enfrentamientos internos entre los diferentes sectores implicados en la sublevación, como demuestran las constantes quejas de la derecha católica y los monárquicos ante el Cuartel General por las descalificaciones de que eran objeto por los falangistas ${ }^{2}$, y el peligro de que con el tiempo se produjesen diferencias insalvables entre las dos principales milicias combatientes ${ }^{3}$. También hay que tener presente el interés de ciertos sectores -en particular de quienes luchaban codo a codo en los frentes de batalla- en avanzar por la senda de la integración, así como los diversos proyectos de "partidos» más o menos artificiales que se iban conociendo. El Decreto de 25 de septiembre de 1936 ya había dejado claro que lo prioritario era asegurar la unidad absoluta frente al común enemigo, prohibiendo todas las actuaciones políticas y las sindicales obreras y patronales que significasen inclinación o parcialidad a favor de determinadas ideologías. La necesidad de un alejamiento absoluto de todo partidismo político estaba ya presente en su Exposición de Motivos, en la que se atribuía al Ejército el carácter de símbolo efectivo de la unidad nacional, aplazando sine die el desarrollo de una actividad política y sindical.

La situación interna de las Milicias, tanto en el frente como en la retaguardia, creemos que fue un elemento determinante en la decisión del Caudillo. Los numerosos conflictos entre jefes y milicianos de una y otra transcendían frecuentemente a la prensa, incluso en zonas en las que,

\footnotetext{
2 Para el caso de Ourense vid. Prada Rodríguez, J., "Que es la voz de la tierra y los muertos, y es mandato de España y de Dios". Las JAPA en Ourense (1934-1937)", en Minius, VII, 1999, págs. 187-221.

3 J. Arrarás, siempre proclive a minimizar los enfrentamientos internos entre la coalición de intereses que sostenía a los sublevados, llega, sin embargo, a reconocer este riesgo de mantenerse la situación existente en julio del 36 (vid. Arrarás, J., Historia de la Cruzada, Madrid, Ediciones Españolas, 1940-1944, vol. VIII, t. 36, pág. 399).
} 
como Galicia, el control del Ejército sobre aquéllas era absoluto ${ }^{4}$. El masivo aluvión de "voluntarios» que nada tenían que ver con el ideario que las inspiraba era un factor de inestabilidad añadido que el propio Franco no dejaba de observar ${ }^{5}$. En su afán por justificar la unificación, cuando ésta ya había sido consumada, el delegado de Prensa y Propaganda de Falange en Allariz acertaba a describir la situación anterior en los siguientes términos:

«La diversificación anterior tenía mucho de artificiosa; frecuentemente no iba más allá del color de la camisa o de la gorra. Muy al contrario, la unidad presente es el hecho naturalísimo reclamado por el fondo mismo de las cosas y por las necesidades ineludibles del momento. Era un dolor que jóvenes, a los que no separaba ninguna razón básica de ideal o de sentimiento patrio, se hiciesen la guerra sin cuartel por la futesa de un nombre, de un viva o de un número. Alguna vez también, y era lo peor, los que no podían luchar por altos y nobles afanes (...) hacíanlo a base de politiquerías y aun de rencillas personales, malogrando así ricas energías juveniles de las que están tan necesitada la patria. (...) ¿Qué táctica de adaptación, qué fórmula de supervivencia sería ignorada de estas viejas hiedras que treparon siempre por los muros de la Patria, chupando su mejor sustancia y disimulando la ruina que le trajeron entre su hojarasca? También en la ocasión presente quisieron ensayar su fórmula de perennidad; juzgaron aparecer a tono con el momento improvisando unas milicias con el marchamo del partido respectivo, y no precisamente para conquistar fortines en las líneas de fuego, sino más bien para hacerse con posiciones políticas ventajosas para el mañana $\times{ }^{6}$.

Y no sólo en la «base». Tampoco resultaban especialmente fluidas las relaciones entre los responsables provinciales del Ejército y de las Milicias,

\footnotetext{
4 Vid., p. ej.., La Región, 31-VII-1936 y 11-X-1936.

5 Es conocida la conversación sostenida entre Franco, el conde de Rodezno, Martínez Berasain y Ulibarri en Salamanca el 12 de abril de 1937 en la que aquél hizo patente su impresión acerca de que «la masa de significación izquierdista se afilia a Falange mientras que la de derechas lo hace en el Requeté, con lo que nuevamente se crearían en España las eternas disensiones entre derechas e izquierdas con la consecuente lucha de clases (...) ") (Acta de la Asamblea Extraordinaria de la CT de Navarra, cit. en THOMÀs, J.M. a, Lo que fue la Falange, Barcelona, Plaza \& Janés, 1999, pág. 165). Ourense no es, precisamente, el mejor ejemplo de lo acertado de esta percepción, ya que lo más común fue que los elementos de significación izquierdista buscasen el amparo del Requeté para escapar de la represión llevada a cabo por los falangistas. En este caso nada tienen que ver las cuestiones ideológicas sino la mera supervivencia táctica: en la mayoría de las aldeas, Falange se organizó tras la sublevación antes que los tradicionalistas y, donde ya existía con anterioridad, estaba mucho más penetrada por elementos de significación monárquica y católica; en este universo rural donde todos se conocían no era posible que anteriores concomitancias fueran desconocidas, lo que es obstáculo para que FE-JONS atrajese, como había ocurrido antes de julio del 36 , a algunos izquierdistas que creían en su pretendida revolución o, simplemente, buscaban el mejor acomodo posible.
}

6 Rumbo, 18-V-1937, pág. 4 
en particular en materia de reclutamiento. Muchas secciones locales de Falange, con sus respectivas milicias de segunda línea, habían sido apresuradamente organizadas por mandos militares cumpliendo órdenes de la Comandancia Militar. En teoría esto debería haber favorecido que FEJONS dispusiese de grandes facilidades para atraer voluntarios con destino al frente por su mayor proximidad a los potenciales destinatarios del mensaje y el control ejercido por aquéllos; sin embargo, el peligro de que sus responsables pudiesen utilizar esta capacidad de movilización para exigir determinadas contrapartidas hizo que los militares se resistiesen a cederles la iniciativa en un ámbito tan sensible.

En el mes de agosto de 1936 se dictó la primera medida práctica destinada a poner freno al incesante proceso de crecimiento que las unidades bajo control falangista y requeté estaban experimentando. Se trataba de una disposición según la cual los voluntarios con destino en alguno de los frentes de la guerra estaban obligados a permanecer en las unidades en las que fueran asignados de forma voluntaria o forzosa, debiendo pasar las milicias que se encontraban en la retaguardia a unidades del Ejército regular. Un posterior Decreto del 25 de septiembre prescribía que los obligados a incorporarse a filas que ya estuviesen encuadrados en cualquiera de las milicias y estuviesen en primera línea, disponían de un plazo de un mes para efectuar su presentación a los respectivos Cuerpos. A pesar de estas disposiciones, según el clásico estudio de R. Casas, en el mes de octubre de 1936 había más de treinta y seis mil falangistas en los frentes, además de veintidós mil carlistas y más de seis mil milicianos de otras tendencias ${ }^{7}$. En realidad, el seguimiento de las diferentes órdenes de concentración publicadas en el BOE contribuyen a explicar el crecimiento del voluntariado miliciano: la inaplicabilidad real de las medidas tendentes a incorporar a la totalidad de los milicianos que se encontraban en el frente a unidades regulares. Así una Orden del 22 de febrero de 1937 relativa a la incorporación a filas de los reclutas de ese año, disponía en su art. 7 que los que entonces estuviesen prestando servicio de armas en los frentes de combate integrados en las milicias podrían continuar sirviendo en ellas durante un mes, transcurrido el cual deberían reincorporarse al Cuerpo o Centro de destino; sin embargo, una disposición dictada cuatro días más tarde modificaba la orden anterior en el sentido de dispensar de su incorporación a filas a los afiliados a las diferentes milicias, siempre que se en-

\footnotetext{
7 CASAS DE la VEGA, R., Las milicias nacionales, Madrid, Editora Nacional, 1977, vol. 1, pág. 269; sobre las milicias carlistas sigue siendo imprescindible el trabajo de ARósTEGUI, J., Los combatientes carlistas en la guerra civil española 1936-1939, Madrid, Fundación Hernando de Larramendi, 1991, II T.
} 
contrasen en el frente como mínimo desde un mes antes a la fecha del llamamiento militar ${ }^{8}$. Esto venía a tratar de corregir situaciones que hemos podido documentar con bastante frecuencia en la provincia: había milicianos que solicitaban incorporarse a alguno de los frentes sólo unas semanas antes de que su quinta fuese llamada a filas, posiblemente esperando un tratamiento más favorable en las unidades de alguna Milicia Armada.

Según J. L. Rodríguez, los responsables de FE de las JONS terminaron por aceptar la sumisión, reconociendo que la eficacia combativa de sus unidades sería mayor si permanecían subordinadas al mando militar y a las exigencias de campaña. Las unidades falangistas, aseguraba Hedilla al general Mola a mediados del mes de septiembre, «serán en todo caso, y tal como ha sido determinado por la autoridad militar, instruidas por mandos militares, los cuales serán quienes las dirijan al ser enviadas al frente" ${ }^{9}$. En noviembre, el Generalísimo se plegaba a la solicitud de Agustín Aznar, por entonces jefe nacional de Milicias, reconociendo los cargos desempeñados por el personal de milicias y su equiparación a grados militares; inteligente maniobra que le permitió disponer al mismo tiempo que el mando de las Banderas de Falange correspondería en adelante a oficiales superiores del Ejército, bloqueando así las aspiraciones últimas de los seguidores de José Antonio.

Los abusos y la indisciplina reiteradamente acreditados por las unidades de milicias explican, en parte, las difíciles relaciones entre oficiales del Ejército y sus mandos; pero lo esencial parece haber sido el temor de que pudiesen consolidarse como un contrapoder. El primer incidente serio se produjo a principios de diciembre de 1936. Los carlistas, fieles a su tradicional política de edificar un Estado paralelo aprovechando la coyuntura bélica, dieron a conocer el día ocho de este mes un decreto firmado por Fal Conde mediante el que se creaba la Academia Militar de Requetés, se regulaban los ascensos por méritos de guerra y se incidía en la formación religiosa y política de los mandos dentro de la línea habitual de la organización. Si con la primera se pretendía mejorar la formación de los oficiales

\footnotetext{
\& Una nueva Orden del 6 de marzo de 1937 referida a los reclutas del $2 .^{\circ}, 3 .^{\circ}$ y $4 .^{\circ}$ trimestre del año confirmaría esta dispensa, sin embargo, permitia intuir la pretensión de reducir la picaresca y el volumen de efectivos prescribiendo que sólo alcanzaba a los que estuviesen prestando servicio de armas con anterioridad al 15 de febrero, mientras que en las precedentes era suficiente con llevar un mes en los frentes de batalla. En todo caso, se preveía que el general segundo jefe de las Milicias Nacionales debía velar por la remisión a las Cajas de Recluta respectivas de las relaciones de los quintos que se encontrasen en esas condiciones, especificando las unidades a las que pertenecían para su constancia oficial.

9 Rodríguez Jiménez, J. L., Historia de la Falange Española de las JONS, Madrid, Alianza, 2000, pág. 250.
} 
del Requeté -que hasta entonces fueran nombrados por la Comunión sin que nadie lo discutiese-, el segundo de los aspectos no podía más que suscitar las iras del alto mando. El propio Franco interpretó la medida como una especie de golpe de Estado encubierto que, además, afectaba a su propio caudillaje desde el momento en que su aceptación significaría la consolidación de un ejército paralelo sobre el que tendría un mando relativo. Las muestras de independencia dadas por los carlistas terminaron con el exilio en Lisboa del presidente de su Junta Nacional sólo doce días más tarde de poner su firma en la citada disposición. A pesar del descontento con el que fue recibida la decisión de los que tenían encomendada la dirección de la guerra, los tradicionalistas se mantuvieron, como no podía ser de otra forma, sin fisuras dentro del bando nacional. En Ourense la polémica no levantó grandes ampollas, más preocupados los ourensanos con sus propias luchas internas con relación al grave problema sucesorio que planteara la muerte en el mes de septiembre de Alfonso Carlos de Borbón y Austria y la consolidación de la regencia en manos del príncipe Javier de Borbón-Parma.

El incidente con el tradicionalista fue la gota que colmó el vaso, pero ya con anterioridad se habían producido algunos conflictos con los falangistas que mostraban sus pretensiones de actuar autónomamente en las cuestiones relativas a la organización de las milicias y en la difusión de la propaganda. Así aconteció cuando el Cuartel General denegó el permiso para que una treintena de falangistas supervivientes del asedio del Alcázar realizase una visita a Zaragoza llamados por el jefe Territorial de Aragón, Jesús Muro, para infundir ánimos a sus acólitos que combatían en el frente aprovechando la festividad del doce de octubre; a pesar de la negativa, los toledanos partieron cinco días antes en viaje de propaganda hasta que Franco cursó, a través del gobernador militar de Toledo, Heli Rolando de Tella, una orden de arresto al Ejército del Norte ${ }^{10}$. Igualmente serio fue el litigio suscitado a raíz del intento de difundir por su aniversario el famoso discurso de José Antonio del 2 de febrero de 1936 en el cine Europa de Madrid, considerado una de las más encendidas prédicas revolucionarias del Ausente; las quejas de la derecha tradicional por los ataques de que periódicamente eran objeto, aconsejaron al delegado de Prensa y Propaganda, Vicente Gay, prohibir su difusión, orden que fue desobedecida por algunas jefaturas provinciales produciéndose algunos incidentes -sobre todo en Valladolid y Salamanca- y detenciones por la Policía que causaron lógico malestar.

10 El incidente está narrado con todo lujo de detalles en JEREZ RIESCO, J. L., Falange imperial (Crónica de la Falange Toledana), Madrid, FN Editorial, 1998, págs. 310 y ss. 
Los ourensanos no disponían por entonces de un órgano de prensa propio, por lo que la polémica no trascendió públicamente; cuando dispusieron de él, optaron por la muy diplomática solución de insertar fragmentos escogidos de sus discursos justo debajo de la cabecera ${ }^{11}$. Tampoco eran bien recibidos ciertos artículos empeñados en denunciar reiteradamente la ruindad de los conservadores locales, cómodamente instalados en la retaguardia mientras lo mejor de la juventud española, naturalmente falangista, regaba con su sangre los campos de batalla ${ }^{12}$; los gobernadores militar y civil-ambos compartían idéntico grado y uniforme- hubieron de llamar al orden al delegado local de Prensa y Propaganda advirtiéndole, en rigor sin demasiada energía, de lo perjudicial que semejante campaña resultaba para la «unidad de espíritus y mando».

Hedilla, por su parte, llevaba tiempo "descontando" una próxima victoria nacional con una serie de declaraciones que hasta el más ingenuo interpretaría como un intento de reafirmar la posición política de Falange ante el eventual reparto de prebendas. Sus intervenciones más aplaudidas y reproducidas eran, precisamente, aquellas en las que reclamaba para aquélla la tarea de la gobernación del Estado, a la vez que insistía en la no renuncia a la consecución de los objetivos más incómodos de su programa. Semejantes pretensiones no podían pasar desapercibidas en Burgos, como tampoco podía hacerlo el culto a su personalidad -uno de los pretextos aducidos por sus rivales para forzar su destitución el dieciséis de abril- que estaba surgiendo en su círculo de colaboradores ${ }^{13}$. Por último,

11 En su edición del 16 de abril Rumbo seleccionaba el siguiente párrafo: «El capitalismo reduce al final a la misma situación de angustia, a la misma situación infrahumana del hombre desprendido de todos sus atributos, de todo el contenido de su existencia, a los patronos y a los obreros, a los trabajadores y a los empresarios»; dos días más tarde escogía este otro: "Desmontaremos el aparato económico de la propiedad capitalista que absorbe todos los beneficios, para sustituirlo por la propiedad individual, por la propiedad familiar, por la propiedad comunal y por la propiedad sindical».

12 Como ejemplo puede verse el siguiente fragmento publicado en Rumbo, 17-IV-1937, pág. 4: «Son muchos los que parecen olvidar que la guerra está en pié (sic) y de que allí, en los frentes de muchas partes de España siguen corriendo a diario la sangre de esforzados y valientes patriotas que, no teniendo riquezas que perder, no obstante, sufren, se sacrifican y hasta mueren por defender el honor y la integridad de la Patria, mientras otros, los adinerados, los ricos en bienes de fortuna, y muchos de ellos culpables de actual estado de cosas, derrochan a manos llenas un dinero, herencia de sus antepasados, sin acordarse de hacer algo en bien de la colectividad. Su egoísmo y ambición los hace considerarse grandes patriotas, porque en su día donaron unas monedas de plata para el Movimiento Nacional, unas monedas entregadas bajo los imperativos de la vergüenza o con la esperanza lisonjera de ver su nombre en las columnas de algún periódico. (...) Tiempo llegará en que aparezca un nuevo Jesús que hará justicia con estos mercaderes indignos de la España Nueva (...)».

13 En toda la prensa falangista se pueden rastrear numerosos comentarios y editoriales que tendían a poner de manifiesto la procedencia "proletaria» del metalúrgico santanderino frente al 
el anuncio de la creación de centros de formación para alféreces provisionales y la convocatoria de varios cientos de plazas para personal en el Ejército del Norte a las que podían concurrir milicianos militarizados, sirvieron para que la Junta de Mando hiciera públicas sus aspiraciones de contar con Academias propias. Era mucho más de lo que el Cuartel General estaba dispuesto a tolerar: sólo los servicios que sus milicias y voluntarios prestaban a la «causa nacional» en frentes y retaguardia hizo que se optase por su «militarización» en lugar de por la simple disolución ${ }^{14}$.

Un Decreto de fecha 19 de diciembre estipulaba que las milicias quedaban obligadas a admitir a oficiales del Ejército de rango inferior, y veinticuatro horas más tarde se procedía, por una disposición de idéntico rango, a su sujeción al CJM. De este modo quedaban asimiladas al Ejército y pasaban a ser dirigidas por mandos profesionales, ya estuviesen de guarnición en los frentes o en las provincias (arts. $1 .^{\circ}, 2 .^{\circ}$ y $4 .^{\circ}$ ); las que prestasen servicio de orden público en aldeas o localidades de retaguardia quedaban sujetas en sus procedimientos a la cartilla de la Guardia Civil y como tal obligadas a levantar atestado de toda detención o suceso en el que interviniesen (art. $6 .^{\circ}$ ). El precepto prohibía, asimismo, que en caso de movilización se retirasen del puesto asignado o se procediese a su desmovilización sin autorización expresa de la autoridad militar competente (art..$^{\circ}$ ), restringiendo su presencia a formaciones de Infantería o Caballería. A cambio conservaban su denominación, sus respectivos emblemas y símbolos, sus afiliados podrían cumplir los correctivos que se le impusieran en los cuarteles propios o locales determinados por la autoridad militar y se les reservaba un determinado número de plazas para su personal que aspirase al empleo de alféreces provisionales.

Desaparecía, así, todo resto de autonomía de las milicias y se completaba la completa subordinación al Ejército de todas las unidades combatientes. Según J. M. ${ }^{a}$ Thomàs, Hedilla intentó forzar una reforma de su articulado que permitiese mantener la autoridad de las organizaciones po-

origen burgués de otros competidores. Por escoger una exaltación próxima a los acontecimientos que estamos narrando se puede ver el comentario de José García Camba en el órgano oficial de Falange en la provincia con motivo de su discurso del 14 de marzo conmemorativo del aniversario de la detención de José Antonio: «No era el discurso improvisado por el demagogo fácil, por el abogado brillante y charlatán, por el burgués pedante que se siente un día "amigo del pueblo" para arrastrar a la gente a sus crecimientos personales. Era el discurso, era la homilia trabajada pacientemente, con tenacidad de remachador de planchas aceradas. Era la oración preparada en muchos días de labor, con esfuerzo casi muscular (...)" (Rumbo, 14-IV-1937, pág. 4). Antes, el 3 de marzo, le había dedicado un encendido comentario laudatorio con el significativo titular de "Manuel Hedilla, obrero de España".

14 Serrano Suñer, R., Memorias, Barcelona, Planeta, 1977, pág. 168. 
líticas sobre sus unidades, pero solamente obtuvo de Franco vagas promesas en el sentido de no obstaculizar el desarrollo y gobierno de las milicias falangistas ${ }^{15}$. La Junta de Mando no renunció, sin embargo, a su pretensión de formar sus propios cuadros militares. Su máximo responsable no tardó en anunciar la creación de varias academias -entre ellas una en A Coruña- para las que solicitó el envío de instructores alemanes a través del embajador Von Faupel. Finalizados los primeros cursos, Falange pretendió que sus titulados fuesen equiparados a los alféreces, pero su pretensión fue radicalmente desestimada, con lo que la formación de oficiales quedó restringida a las Academias Militares.

Este mayor control de los militares sobre las unidades de milicias no se tradujo en un descenso significativo de los enfrentamientos en nuestra provincia. Nada más lejos de la realidad a juzgar por toda una serie de incidentes en los que se pone de manifiesto la importancia que para los responsables de las milicias representaba ese potencial de negociación que giraba en torno al reclutamiento. Viejas y nuevas elites locales, rancios muñidores de la denostada política pseudoliberal y jóvenes advenedizos deseosos de hacerse un hueco en la misma, experimentados actores y noveles aspirantes no muestran el menor empacho en defender con uñas y dientes sus parcelas de poder, ya sea ante las autoridades provinciales de Falange y los Requetés ${ }^{16}$, ya ante los propios mandos militares ${ }^{17}$. Los ejemplos son numerosos, pero todos ellos tienen en común la energía con la que se empleó el gobernador militar para ponerles coto en cuanto amenazaban con degenerar, no ya en una manifestación de disidencia sino

15 THOMÀs, J. M.a, "Actas de las reuniones de la Junta de Mando provisional de Falange ESpañola de las JONS celebradas durante el período 5 de diciembre de 1936-30 de marzo de 1937», en Historia Contemporánea, n. 7 , 1992, pág. 346.

16 Un documento reutilizado como borrador de los diferentes desarchivos de la causa 33/1937 procedente de la Comisaría de Ourense aseguraba que el párroco de Barbadás «(...) organizó la sección [de Requetés], siendo su único responsable, pues es de pública notoriedad que en nada cuenta con la provincial». La influencia de los párrocos en las organizaciones locales de Falange también se ponen de manifiesto en otro informe procedente de la misma instancia incorporado al expediente $n{ }^{\circ} 99.772$ al referirse al párroco de Berán (Leiro) como el «verdadero animador de aquella Falange en la que militó el J.G, desde el mismo momento de su constitución, poniéndose en todo a disposición [del sacerdote] (...)" [Archivo de la Comisaría de Investigación y Vigilancia de Ourense $(\mathrm{ACO})]$.

17 Por ejemplo, en enero de 1937 el párroco de Córcoces (Avión) y el jefe local de Falange de San Xusto (Avión) intentaron presionar al jefe provincial de Falange, el teniente de Carabineros Salvador Buhigas Novo, para que intercediese delante de las autoridades militares, «manifestando que mientras no fuesen puestos en libertad el ex-Delegado gubernativo de Avión, D. Jaime Cabo y el cura párroco de S. Justo de Avión, D. Juan González Cota, no saldrían para el frente los falangistas que voluntariamente se habían anotado para este fin por el que se suscribe y demás personal auxiliar de Falange, dando esto lugar al consiguiente escándalo y revuelo (...)» [Archivo General Militar de Ourense (AGMO), causa 57/1937, fol. 1a]. 
en un simple incidente susceptible de transcender públicamente y poner en peligro la «unidad de mando». La jurisdicción de guerra era una permanente espada de Damocles con la que pocos se atrevían a lidiar, a pesar de lo cual no faltó quien hubo de comparecer ante ella para dar cuenta de tan poco edificantes pretensiones. Para ocasiones menos trascendentes, tan variopintas como numerosas, era suficiente con el recurso a la potestad gubernativa en forma de multas y arrestos, casi siempre cumplidos en sus propios cuarteles y sólo excepcionalmente en alguna de las prisiones o depósitos provinciales ${ }^{18}$.

\section{EL CAMINO HACIA LA UNIFICACIÓN}

Falangistas y tradicionalistas no permanecieron indiferentes a los movimientos que se estaban produciendo desde el cuartel general de Franco, pero, como señala acertadamente J. Tusell, sería la situación particular de las diferentes fuerzas que apoyaban el golpe la que iba permitir al Ejército imponerse sin excesivos problemas ${ }^{19}$. Sus respectivas jefaturas mantuvieron diversos contactos entre sí, marginando a los mandos de la JAP, desde finales de diciembre animadas por los rumores de una unificación que tendería a reforzar el mando único y a crear un «partido franquista». Incluso ciertas declaraciones, que más bien semejaban caminar entre lo retórico y el deseo de sumarse sin demasiado entusiasmo a lo que políticamente comienza a aparecer como más correcto, afirman la existencia por entonces de una tendencia hacia la formación de una fuerza única ${ }^{20}$. Estos contactos iniciales, lo mismo que las conversaciones formales llevadas a cabo entre febrero y abril de 1937 en Lisboa y Salamanca fracasaron estrepitosamente; a pesar de esto, en la capital lusa se llegó a un acuerdo según el cual no se admitiría intervención de tercero en sus relaciones, ambas fuerzas renunciaban a cualquier tipo de inteligencia con otras agrupaciones políticas y se opondrían a la constitución de cualquier gobierno civil que no estuviese formado exclusivamente por representantes de ambas.

Ninguna de las dos fuerzas ignoraba que desde el Cuartel General se preparaba una solución por decreto, pero la imposibilidad de llegar a

18 Vid., por ejemplo, la sanción impuesta a un requeté por negarse a colaborar con la fuerza pública (ACO, expediente 101.543).

19 TUSELL, J., «El proceso hacia la unificación», en la Guerra Civil, Madrid, Historia 16, 1986 vol. 11, pág. 60.

20 Arriba España, 6-1-1937; cit. en Aróstegul, J., «Los dos Estados», en la Guerra Civil, Madrid, Historia 16, 1986 vol. 11, pág. 34. 
acuerdos concretos pone de manifiesto las dificultades para fusionar dos conglomerados tan dispares, la desconfianza mutua existente y el enfrentamiento entre partidarios y contrarios de la unificación. Así, mientras desde el exilio Fal Conde mantenía sus reticencias y Don Javier se apartaba cada vez más de Franco, los navarros y Rodezno presionaban por la sustitución del primero y se pronunciaban claramente por ésta a principios de abril. De hecho, en la reunión de la Junta de Mando de Falange del 30 de marzo, se aprobó elevar un escrito a Franco reclamando para sí la tarea política de dirigir la gobernación del país, salvo en los departamentos de Guerra y Marina, lo que venía a demostrar la fragilidad de un pacto que no contaba con el apoyo unánime de todos los dirigentes. Por eso no sólo la intransigencia mutua, que también existió y terminó por parecer insalvable -en particular las pretensiones hegemónicas de los falangistas-, sino las disensiones internas y la abierta lucha por el poder que se libraba en el interior de la CT y de FE de las JONS aparecen como las causas principales del fracaso de las negociaciones.

También Falange se encontraba bastante fraccionada a pesar de la jefatura nominal ejercida por Hedilla a raíz de la muerte del Ausente. Además del cantonalismo en que seguían moviéndose no pocas organizaciones territoriales en la zona controlada por Franco, pronto hubo de afrontar el ataque de ciertos mandos descontentos con su liderazgo, algunos de los cuales, como Garcerán o Dávila, le debían su nombramiento. Según S. G. Payne a principios de 1937 tres tendencias se disputaban su control ${ }^{21}$. El sector mayoritario se agrupaba alrededor del santanderino, que tenía sus principales apoyos entre los jefes provinciales de la zona norte, incluida la territorial gallega; sus partidarios -entre los que se encontraban todos los intelectuales- mostraban un gran espíritu revolucionario y una mayor conciencia social, y no pocos de ellos veían en Alemania el referente inmediato pensando no tanto en una orientación ideológica sino en el apoyo material y la capacitación técnica de la que estaban tan necesitados. Un segundo grupo estaría formado por el que el hispanista denomina legitimistas, es decir, los seguidores más estrictos y formales de José Antonio, entre los que se encontraban Agustín Aznar, Rafael Garcerán y Sancho Dávila, así como la mayoría de los dirigentes andaluces y los nuevos responsables de Valladolid, José Antonio Girón y Luis González Vicén; rechazaban cualquier cambio no inspirado en sus discursos y escritos y se oponían a la jefatura de Hedilla sin ofrecer más alternativa que la de la Junta de Mando, dentro de la cual lo consideraban un miembro más. Por

21 PAYne, S. G., Falange. Historia del Fascismo, Madrid, Sarpe, 1985, págs. 161-162. 
último, el conglomerado neofalangista, formado por un heterogéneo grupo de recién llegados que tenían como principal objetivo apoderarse de la organización e imprimirle unos trazos más conservadores; entre las hipótesis de futuro que barajaban estaba una fusión con los carlistas que permitiría poner fin al incómodo discurso obrerista y pseudorrevolucionario como tributo a la "tradición», lo que explicaría su participación en las conversaciones previas emprendidas por ambas fuerzas políticas.

Paralelamente, la prensa falangista fiel a Hedilla publicaba unas largas declaraciones a tres columnas en las que el santanderino daba su particular visión sobre el falangismo y la España futura ${ }^{22}$. Preguntado sobre la posición de FE de las JONS sobre la Monarquía, Hedilla respondió que la eventualidad de una restauración era algo que sólo podía contemplarse a muy largo plazo, cuando el nuevo Estado gozase de una sólida arquitectura. "Mientras tanto, Falange considerará delito de "lesa patria" atentar a la unidad de pensamiento de los colaboradores de Franco, los cuales quieren una España totalmente diferente de las viejas Españas monárquica, republicana y roja sobrepuesta a la España eterna". Respecto a la naturaleza del "nuevo Estado» insistió en la necesidad de integrar en él a las clases populares, incluidas las de la zona «no liberada», respecto a las que proponía «tender la mano abierta a las masas convencidas por la propaganda demagógica y por la injusticia social que hacía siglos reinaba en España». De esta consideración emanaba la necesidad de hacer honor al lema de José Antonio «Justicia para los Jefes, piedad para los subordinados», razón por la que «la dirección nacional de Falange española ha prohibido desde hace tiempo a los propios afiliados el fusilamiento de rojos, y esta orden ha sido repetida de manera perentoria en las ciudades $y$ en los pueblos recientemente ocupados».

Aún más radical era su posición respecto a la constitución del nuevo Gobierno, que debía ser intérprete de «la voluntad de la juventud que combate en nuestras líneas y en las de nuestros adversarios", siendo la exaltación del trabajo «el paso decisivo para la abolición de las clases (...) [pues] los combatientes de las dos partes aspiran a hacer que la dignidad y la consideración del hombre como portadoras de los valores humanos, dejen de permanecer en los conceptos teóricos del Estado y se conviertan en normas de conveniencia". En este diseño reservaba al Ejército un papel puramente «técnico", dotado de un "concepto del deber hacia la Patria y exclusivamente hacia la Patria, que lo aleje de toda aventura po-

22 Rumbo, 18-IV-1937, pág. 4; se trata de la versión publicada en España de unas declaraciones realizadas a // Regime Fascista días atrás. 
lítica». Por el contrario, defendía la necesidad de crear una milicia nacional de ex-combatientes «que deberá ser la guardia armada de la revolución para darle consistencia y un carácter permanente, lo cual sería imposible si la guardia de la revolución fuese confiada al Ejército».

En materia religiosa se limitó a reproducir el vigésimo quinto punto del ideario falangista, insistiendo en la necesidad de separar Iglesia y Estado, mientras que en el apartado agrario ratificaba las pretensiones de realizar «sin titubear» la reforma agraria que el país necesitaba. También se reafirmó en las conocidas doctrinas con relación a la organización corporativa de la sociedad mediante un sistema de sindicatos verticales por cada ramo de la producción «al servicio de la integridad económica nacional», repudiando a un tiempo al sistema capitalista por inhumano y al marxista por «antinacional».

Finalmente, son muy significativas sus declaraciones sobre cómo veía las relaciones con los tradicionalistas. Hedilla, reafirmándose en todos los puntos del ideario de Falange, no escondía sus pretensiones de absorber la parte más «sana» de la Comunión, mientras el resto, lo más vetusto, acabaría por desaparecer:

«La fuerza del tradicionalismo se compone de dos partes desiguales: una es el partido Tradicionalista... La otra formada por requetés, muchachos fuertes y sanos, que sin saber considera el viejo dicho "Dios, Patria y Rey" y sienten en el fondo de su alma nuestro "Por la Patria, el Pan y la Justicia". Estos muchachos, camaradas de los falangistas en la trinchera, se encontrarán satisfechos con la camisa azul en algún día más o menos próximo, como los exnacionalistas italianos con la camisa negra. Esta juventud vendrá con nosotros y el viejo tradicionalismo se deshará como todo lo viejo de España».

Las luchas de poder que se desarrollaban en el interior de Falange y la CT y el problema de la división interna que en las filas nacionales planteaba el discurso radical de algunos falangistas enlazan directamente con la cuestión que nos ocupa. Goicoechea fue el encargado de abrir fuego anunciando en un mitin pronunciado en Salamanca el ocho de marzo que estaría dispuesto a realizar «todos los sacrificios posibles» para la constitución de un único partido o de un «frente patriótico" que sirviese de punto de partida para la creación de una estructura totalitaria de carácter orgánico; muchos no dejaron de observar en sus declaraciones una maniobra táctica para presionar a favor de una unificación que le permitiese recuperar parte de la influencia perdida. El día doce de abril Franco anunció a una comisión carlista encabezada por Rodezno, Ulibarri y Berasain la inminencia de una unificación por decreto de las distintas fuerzas existentes 
en la «zona nacional». Veinticuatro horas más tarde, Hedilla, sabedor de las maniobras para destituirlo y nombrar en su lugar a un triunvirato que dirigiese Falange, convoca, sin dar cuenta a la Junta de Mando como era preceptivo, un Consejo Nacional extraordinario que debería juntarse en Burgos el día 25 de ese mes con la intención de fortalecer su posición y convertir su inestable mando en jefatura nacional. Sus opositores decidieron anticiparse y se juntaron en Salamanca en la mañana del dieciséis de abril, conscientes de que si dejaban en manos del santanderino la iniciativa éste no dudaría en hacer uso de los estatutos para nombrar un núcleo de consejeros adictos que avalasen sus pretensiones.

Los conjurados procedieron a la destitución de Hedilla de todos sus cargos -incluido el de jefe territorial de Burgos- sin base reglamentaria alguna, eligiendo seguidamente un triunvirato formado por Aznar, Dávila y Moreno, con Garcerán actuando de secretario. Seguidamente convocaron al jefe de la Junta de Mando para darle cuenta de un largo escrito de acusaciones entre las que figuraban sus presuntas maniobras a favor de la unificación por haber declarado en el mes de enero que no podía negar una «tendencia a la formación de una fuerza única» que pasaba por la asunción de FE y de las JONS de aquellos puntos del programa tradicionalista "compatibles con las necesidades del momento». Sólo el desconocimiento que entre muchos mandos se tenía de las intenciones del Caudillo y las intrigas contra el dirigente santanderino -la razón última de las acusaciones, pues no parece que fuese un partidario acérrimo de la unificación sino que más bien trabajaba con varios escenarios posibles sin descartar ninguna opción-pueden explicar este proceder, porque si algo parecía evidente era la imposibilidad de oponerse a una medida largamente meditada por más que el pretexto para su ejecución la proporcionasen los sucesos de Salamanca.

Franco, puntualmente informado, dispuso que a través del Cuartel General se cursasen instrucciones precisas a todos los gobernadores militares vedando la difusión de cualquier información relativa a estos sucesos; más tarde, previendo movimientos a favor del destituido, al que reiteró su confianza, prohibió la salida de milicianos de cualquier plaza sin autorización expresa y la detención de enlaces forasteros hasta que no aclarasen la naturaleza de su viaje. Mientras, Hedilla contraatacaba concentrando en la ciudad a sus seguidores, y en la mañana del día diecisiete cursaba órdenes para que el Consejo extraordinario se celebrase al día siguiente en la Jefatura de la Junta de Marido en la capital salmantina; en la madrugada de aquella jornada dos falangistas, uno por cada bando, murieron por disparos cruzados entre grupos contrarios. En este IV Congreso $\mathrm{Na}$ cional estuvieron presentes el jefe provincial ourensano, Fernando Meleiro, y su compañero de Pontevedra, Jesús Suevos, avisados por figurar entre 
la nómina de consejeros nombrados entre 1935 y 1936 que residían en la «zona nacional»; durante el mismo fue elegido jefe nacional bajo la sombra de la anunciada unificación, que finalmente se dio a conocer a las diez y media de la noche del día dieciocho en un discurso radiado de Franco a través de Radio Nacional. Las sesiones se reanudaron por la mañana para debatir sobre las acusaciones y los descargos alegados por unos y otros; también se procedió a al elección de cuatro de los seis miembros de la Junta Política que los estatutos reservaban para el Consejo, recayendo la elección en José Sáinz, Martín Ruiz Arenado, Roberto Reyes y Miguel Merino. Los gallegos regresaron a Ourense esa misma tarde sin que la prensa falangista de la capital diera la más mínima noticia sobre los incidentes que se desarrollaran en las horas previas ni sobre la posición adoptada durante éstos por ambos dirigentes ${ }^{23}$.

\section{LAS PRIMERAS REACCIONES}

El proceso de gestación del Decreto de 19 de abril -en particular el relevante papel jugado por Serrano Suñer en la unificación- y su significado son bien conocidos gracias a las numerosas historias de Falange que han apareciendo en las últimas décadas ${ }^{24}$. En esencia, nacía una nueva fuerza, Falange Española Tradicionalista y de las JONS (FET y de las JONS), resultante de la fusión de Falange y la CT, a las que se les reconocía de este modo su decisiva aportación al esfuerzo bélico y el hecho de encarnar mejor que ninguna otra el auténtico "espíritu del alzamiento nacional». Las restantes organizaciones simplemente quedaban absorbidas 0 , por mejor decir, «disueltas» en el partido único, mientras se aplazaba la cuestión dinástica mediante el eufemismo de remitir a un horizonte futuro la «posibilidad de instaurar en la nación el régimen secular que forjó su unidad y grandeza histórica». Pasaban a ser militantes del nuevo partido los que formaban parte de estas dos fuerzas hasta el momento de la pu-

23 Rumbo se limita a informar sobre su llegada a la capital ourensana y a reproducir una nota de la jefatura de prensa provincial dando cuenta del telegrama remitido desde Salamanca el día diecinueve en el que se informaba de la reunión del Consejo Nacional, los consejeros asistentes y la decisión de éste de nombrar a Hedilla «Jefe nacional del Movimiento, con todas las atribuciones que según los Estatutos le corresponden por tal cargo (...), concedi[éndole] amplias facultades y total confianza (...) para celebrar aquellas entrevistas políticas que, inmediatamente fueran necesarias con las autoridades del Estado» (vid. 20-IV-1937, págs. 3 y 4).

24 PAYNe, S. G., Falange..., op. cit., págs. 174-178; Rodríguez JimÉnEZ, J. L., Historia de la Falange Española..., op. cit., págs. 298-306; ThòmAs, J. M.a, Lo que fue la Falange..., op. cit., págs. 199-204; CHUECA, R., El fascismo en los comienzos del régimen de franco. Un estudio sobre FETJONS, Madrid, CIS, 1983, págs. 126 y ss. 
blicación del Decreto; los demás deberían pasar por el trámite de admisión previa y serían considerados afiliados. En teoría, el predominio del partido fascista parecía indiscutible: sus «veintiséis" puntos -quedaba excluido el último, relativo a la escasa predisposición al pacto de Falange excepto «en el empuje final por la conquista del Estado (...) siempre que esté asegurado nuestro predominio» - se convertían en la norma programática del nuevo Estado totalitario, se copiaba su modelo organizativo y, por medio de un nuevo decreto firmado cinco días más tarde, el saludo fascista se transformaba en «nacional». Los diferentes servicios nacionales que se fueron creando con el paso del tiempo -muchos de ellos coexistiendo paralelamente con los del Estado-, constituyeron un vivero para la provisión de cargos para los militantes, a los que se le retribuía de este modo su compromiso con la organización.

En la práctica, el principal beneficiado de la unificación era el general Franco, convertido en el máximo responsable del nuevo conglomerado, incluidas las respectivas milicias, dotado de un omnímodo poder político reconocido de forma prácticamente unánime en la España «nacional» y con las manos totalmente libres para concentrarse en el esfuerzo bélico. Además, como jefe inmediato de la milicia unida, estaba previsto el nombramiento de un general que tendría a su lado dos subjefes militares, uno por cada una de las entidades fusionadas, y dos asesores políticos designados por el Mando con funciones puramente asesoras; de esta forma el control militar sobre la nueva Milicia Nacional pasaba a ser absoluto, estrangulando antes de producirse tentativas como la imaginada por Hedilla de transformarla en un instrumento al servicio de la revolución nacionalsindicalista. El general José Monasterio Ituarte, los coroneles Ricardo Rada Peral y Darío Gazapo Valdés, serían los primeros elegidos para esta misión mediante el Decreto $n .{ }^{\circ} 272$ de 11 de mayo; como asesores políticos fueron designados Agustín Aznar y Jesús Elisaldo.

Más dificultades existen, como señalaba J. Aróstegui, a la hora de emitir un juicio serio y documentado sobre cómo fue recibido por la masa de la población y, especialmente, por los combatientes en filas dadas las dificultades existentes para expresar públicamente cualquier opinión discrepante ${ }^{25}$. Faltan todavía estudios regionales y locales que permitan responder satisfactoriamente a esta cuestión clave para la acertada comprensión del proceso de conistrucción y de consolidación del franquismo; único modo de ir más allá de las retóricas manifestaciones de unos lí-

25 Afóstegul, J., «Los dos Estados», en La Guerra Civil, Madrid, Historia 16, 1986, vol. 11, pág. 42. 
deres que, prescindiendo de contados casos, por lo demás bien conocidos, parecieron mostrarse encantados de la decisión de Franco. No menos importante resulta separar los distintos niveles de recepción, coincidentes con los diferentes actores implicados en el proceso: las milicias y las fuerzas políticas que aún se resistían a disolverse, el Ejército y el resto de la población. La documentación procedente de los archivos militares y los fondos privados atesorados por antiguos dirigentes de las formaciones que se sumaron a la sublevación permiten avanzar algunas respuestas con relación a los dos primeros actores señalados.

Aún más problemático resulta juzgar la respuesta dada por la masa «neutra» o «indiferente", por los simples «simpatizantes» y, ya no digamos, por los opositores al régimen. Para la mayoría de ellos, a juzgar por las impresiones obtenidas del manejo de fuentes orales, el Decreto de Unificación pasó desapercibido en el sentido de que no significó alteración alguna de sus vidas; la unión de la boina roja y la camisa azul parece que es lo único que la gente recuerda como identificativo de la nueva situación creada, pero hasta esto es minimizado aludiendo a que las milicias conservaron sus uniformes y emblemas distintivos. Las jefaturas locales, incluso después de que se regulase normativamente el uso de los nuevos símbolos, continúan un tiempo manejando los mismos sellos y empleando el mismo papel timbrado, y la nueva indumentaria tarda meses en estar disponible. La percepción colectiva de la unificación, especialmente en el ámbito rural y villano, no parece haberse caracterizado por establecer una nítida separación entre el antes y el después.

Precisamente, el empleo de los respectivos saludos, emblemas e himnos por parte de las distintas milicias fue uno de los focos de conflicto permanentes en la provincia, tanto entre milicianos como entre éstos y los oficiales del Ejército. Cada una de estas entidades tenía su propio reglamento al respecto, y la situación vino a complicarse aún más cuando a finales de febrero de 1937 Franco dictó un decreto que volvía a establecer como himno nacional la Marcha Real, y declaraba «cantos nacionales» el Cara al Sol, el Oriamendi, y el himno de la Legión. J. L. Rodríguez recoge toda una serie de instrucciones, circulares y notas de prensa que demuestran el escaso entusiasmo de los falangistas en la utilización de los símbolos de la monarquía borbónica y su interés en potenciar los suyos propios ${ }^{26}$. No por

26 Rodríguez Jiménez, J. L., Historia de la Falange Española..., op. cit., págs. 269-271; del mismo autor vid. «Incidentes entre Falange y Ejército, 1936-39. El discurso de José Antonio Primo de Rivera en el cine Europa de Madrid (2-II-1936)», en Historia 16, Madrid, n. ${ }^{\circ} 130$, febrero-1987, págs. 19-22. 
esto desaparecieron los problemas, y aún el ministro de Gobernación aclaraba el 6 de febrero de 1939 en un telegrama dirigido a los gobiernos civiles el sentido de la orden relativa al uso simultáneo de camisa azul y boina roja en la dirección de «tener dicha medida carácter general si bien su cumplimiento debe exigirse con preferencia y mayor rigor en militantes y afiliados al partido que en elementos simplemente afectos a Organizaciones Sindicales Obreras» 27.

El reforzamiento del papel del Ejército al que aludíamos explica la unánime satisfacción con que fue recibido el Decreto por los mandos militares ourensanos. En adelante sería reiteradamente citado para justificar todavía un mayor control sobre las milicias provinciales en aspectos especialmente sensibles como el del armamento. Frente a la imprevisión y al descontrol con el que se obrara en los instantes iniciales del golpe, ahora se ejerce una supervisión mucho más directa: sólo cuatro días después de su publicación el comandante inspector de milicias, R. Valcarce, ordenaba a la jefatura de las JAP, la entrega «lo más pronto posible» del armamento que obraba en su poder, exceptuando únicamente el de los milicianos que prestaban servicio de vigilancia en la frontera. Poco después, amparándose en una posterior orden del 11 de mayo, todas las fuerzas auxiliares que prestaban servicio de orden público en las diferentes villas y aldeas de provincia, quedaban encuadradas en la nueva Milicia Nacional bajo las órdenes de los mandos militares. Como señaló el comandante del Batallón de guarnición en la plaza en un poco inspirado discurso dirigido a la multitud que abarrotaba las inmediaciones del Gobierno Militar, se trataba de una medida de transcendencia histórica «en contraposición con el caos de revueltas pasiones que durante el Gobierno del Frente Popular fomentaron el odio y la lucha de clases».

El órgano oficial de Falange ourensana, que en su número anterior aún se regodeaba con las declaraciones de Hedilla relativas a la desaparición de lo más vetusto del tradicionalismo, no ofrecía el más ligero síntoma de disidencia al reproducir el discurso de Franco. Todo lo contrario, bajo el expresivo título de Franco, Caudillo de España, insertaba un comentario que recogía la posición oficial de la disuelta FE de las JONS: la obediencia ciega al Caudillo y al Jefe indiscutible ${ }^{28}$. Nada transcendió, por consi-

27 Boletín Oficial de la Provincia de Ourense (BOPO), 8-II-1939, pág. 1.

${ }_{28}^{28}$ «A TUS ÓRDENES!. La Falange te seguirá como un sólo hombre con ciega fe en tu valentía y en el triunto que se nos ofrece. (...) ¿Cómo no vamos a unirnos Falange y Requeté, si juntos, con nuestra sangre, estamos amasando la España nueva, el Imperio azul? Divididos y enfrentados nos quería la Masonería y la política vieja que pulula por la retaguardia. En trance de rencilla y de 
guiente, del famoso cruce de telegramas de Franco y Hedilla. Como es conocido, el día veintiuno Franco remitió un telegrama a las Divisiones Orgánicas para que sus responsables convocasen a los jefes provinciales y territoriales de las dos organizaciones «advirtiéndoles se pongan en todo caso en relación con esta Jefatura absteniéndose de recibir orden ni consigna alguna por otro conducto». Veinticuatro horas más tarde se recibía en las diferentes jefaturas provinciales otro telegrama con el sello de la Junta de Mando y en el nombre de Hedilla en el que se participaba: «Generalísimo ordenará conducto mando supremo Falange. Sancionaré severamente cualquier iniciativa propia sobre decreto fusión». Fuese este último el autor del texto o fuese José Sáinz como el mismo le aseguraba por carta en mayo de 1947 a raíz de la publicación del libro de Serrano Suñer Entre Hendaya $y$ Gibraltar en el que se responsabilizaba al ex-jefe nacional al tiempo que se le atribuía un matiz claramente subversivo, lo cierto es que en Ourense no nos consta la presencia de incidentes de ningún tipo a diferencia de lo acontecido en otros puntos ${ }^{29}$. Ese mismo día Franco nombraba la nueva Junta Política en la que figuraba el santanderino pero que obviamente no satisfacía las pretensiones de los falangistas, que sólo hubiesen aceptado de buen grado una clara mayoría. Hedilla, aconsejado por varios «camisas viejas», rechazó el cargo que se le ofrecía provocando la contundente respuesta del Cuartel General: una treintena de falangistas fue apresada el día veinticinco y dos semanas más tarde se les abría un proceso judicial. La rígida censura establecida por las autoridades no nos permite conocer si en la provincia se produjo algún acto de solidaridad con los detenidos, pero la tranquilidad pareció ser la nota dominante y seguramente pocos fueron los que tuvieron conocimiento exacto de los hechos.

Cuando se conocieron exactamente los términos del Decreto, el entusiasmo aparente del órgano falangista se hizo, sin embargo, aún más evidente al subrayar, por encima de cualquier otra consideración, que los veintiséis puntos del nacionalsindicalismo serían la base programática del

\footnotetext{
apetito egoísta y personal querría vernos la Anti-Patria. Pero no será así. Por obra y gracia de tu genio político y guerrero. (...) Requetés herederos del espíritu de Zumalacárregui: desde hoy somos hermanos y camaradas en la Falange Española tradicionalista de las J.O.N.S. Somos camaradas y hermanos por una triple voluntad confluyente al fin único de España: nuestra voluntad, la de Franco y la de Dios" (Rumbo, 20-IV-1937, pág. 4).

29 Sobre esta cuestión vid. García Veneno, M., Falange en la guerra de España: La Unificación y Hedilla, París, Ruedo Ibérico, 1967, pág. 397; Jerez Riesco, J. L., Falange imperial..., op. cit., págs. 366-368; PAYNE, S. G., Falange..., op. cit., págs. 175-176; RodRíGuez JIMÉNEZ, J. L., Historia de la Falange Española..., op. cit., págs. 306-308; THOMÀs, J. M. ${ }^{2}$, Lo que fue la Falange..., op. cit, págs. 213-215.
} 
nuevo Estado totalitario. ¿Y el vigésimo séptimo?: «El punto 27, que se refiere a la supresión de todos los partidos de tipo democrático y a la fusión con aquellas fuerzas de identidad ideológica y táctica con la Falange, está ya cumplido con el Decreto 255»30. Curiosa interpretación que tuvo como efecto hacer desaparecer de súbito, como por ensalmo, el último punto del ideario de Falange, lo mismo si los discursos tenían por escenario alguna entidad oficial que si se pronunciaban en alguna sociedad de recreo, como hizo el presidente del selecto Club Ourensano cuando, aprovechando la colocación de un retrato de Franco en su sede, se detuvo oportunamente en la exaltación del reciente decreto ${ }^{31}$. De hecho, para los acomodaticios, la inspirada norma sólo constituía una relativa novedad: los partidos de la vieja política demoliberal agotaran toda su potencialidad en luchas electorales y parlamentarias, quedando definitivamente periclitados en julio del treinta y seis, por lo que el Decreto « no hace sino dar estado jurídico al hecho consumado" y reconocer la "exacta visión política» que el Requeté y la Falange «alcanzaron al preconizar un Estado capaz de enlazar el presente histórico de España con su pasado heroico y triunfal».

En la misma línea de concitar unanimidades se organizó para el día veintidós una «espontánea» manifestación patriótica de adhesión a Franco «por su histórico Decreto sobre unificación de milicias»; una demostración de júbilo que semejaba algo tardía con relación a las que ya tuvieran lugar en las principales capitales de la «zona liberada». Al frente de la misma figuraban las autoridades de rigor y los jefes de Falange y el Requeté, todos detrás de un improvisado lienzo con los emblemas de ambas organizaciones en las esquinas sobre un fondo en el que destacaban, en grandes caracteres, las letras que componían el nombre de la nueva organización ${ }^{32}$. Los discursos de los asistentes no se apartaron un ápice del guión establecido: José Fernández Borrajo, miembro de la Junta Carlista de Guerra y Bartolomé Mostaza, jefe de Prensa y Propaganda de Falange

\footnotetext{
30 Rumbo, 21-IV-1937, pág. 1.

31 La Región, 27-IV-1937, pág. 3

32 Merece la pena transcribir el ambiente reflejado por la prensa católica de la capital, nada casualmente aún más entusiasta en su descripción que la falangista: «Momentos antes de las doce comenzaron a animarse las calles de nuestra ciudad, poblando el ambiente de ruidosa algarabia en un continuo ir y venir de gente que acudió al acto de los más apartados rincones de la provincia. (...) Pocos minutos antes de la hora señalada, un verdadero río de gente comenzó a afluir a la Plaza Mayor, que se hallaba ya materialmente abarrotada de público, donde con una ovación estruendosa fué (sic) saludada la presencia de las milicias de la JAP. Con un general repique de campanas y bombas dió (sic) comienzo la iniciación del magno acontecimiento (...) Los edificios se hallaban profusamente engalanados con los colores de la bandera nacional. Las oficinas y comercios cerrados; los balcones desiertos; las campanas tocando a gloria y las ruas (sic) rebosando gente en un entusiástico fervor patriótico inenarrable» (La Región, 23-IV-1937, pág. 2).
} 
se congratularon del proverbial sentido del Caudillo al saber interpretar tan magistralmente los deseos del pueblo español, pues, como señaló el primero las milicias que luchaban hermanadas en el frente no podian dar en la retaguardia el ejemplo bochornoso de continuas rencillas, aplaudidas sólo con entusiasmo y calor por los enemigos de Patria. El coronel Soto, escasamente dotado para la oratoria, sólo acertó a decir «breve y elocuentemente que unidos todos en un fuerte abrazo gritasen con él: ¡Viva España! ¡Viva España! ¡Viva siempre España!». Hasta el obispo manifestó su contento «porque en Ourense se siguiese esa unidad corporal y espiritual en todas las juventudes que han de formar la España nueva». Los telegramas oficiales enviados a Salamanca por el alcalde, las Juntas de Mando de FET y de las JONS y la Jefatura de Prensa y Propaganda de FE incidían en la misma dirección. El jefe provincial de Falange se limitó a transmitir a Hedilla su felicitación por el «inspirado Decreto, que armoniza entraña histórico tradicional e imperial hispánico con realidades modernas" (sic).

La realidad era algo diferente. El foso entre ciertos sectores de los antiguos camisas viejas y la gran masa de la militancia adherida con posterioridad a febrero y julio de 1936 estaba agrandándose: los más puristas -muy pocos, realmente- y los que veían sus prebendas en peligro como consecuencia de la futura readaptación de mandos que se avecinaba no podían esconder su contrariedad por encima de los gestos públicos, conscientes de que la maniobra ocultaba una operación de homogeneización que sólo podía perjudicarlos. Los de procedencia calvosotelista y cedista y, en general, los más vinculados a la derecha tradicional, saludaban una unificación que parecía destinada a borrar los últimos resabios revolucionarios de la organización gracias al control ejercido por Franco, a quien correspondía, en última instancia, el nombramiento del jefe provincial que, a su vez, era quien elegía a los responsables de cada sección local, para la que bastaban veinte afiliados. Desde 1941 este control sería aún más efectivo una vez que el gobernador civil unió a este cargo el de jefe provincial del Movimiento y que en la provincia será efectiva ya desde 1938.

Como correspondía a tan magno evento, organizose apresuradamente una comida de hermandad de la Junta de Mando de la nueva milicia en el campo del antiguo colegio de los Maristas; eran tiempos en los que había que argumentar inexistentes tendencias a la confluencia orgánica desde antaño, cosa, por cierto, bien diferente de la unidad de acción que se observa desde finales de $1935^{33}$. Por primera vez se podían ver juntos a fa-

33 M. Suárez, acaso tomando demasiado literalmente las informaciones de la prensa, sostiene que en Asturias el Decreto fue bien recibido por Región y Nueva España por la existencia de 
langistas de primera hora con requetés de toda la vida, a camisas nuevas con tradicionalistas sin «tradición». Ahí estaban Meleiro, Romero, Montero, Fernández Borrajo, Suárez, Gallego, Ventosa, Barja, Núñez, Salgado, Gobart, García Hermida, Núñez, Álvarez, Ruiz, Madriñán, Martínez, Rey, Areal, Morais, Areas, Vide, Valencia, Ferreiro, Colemán, Fausto Román... Para que nada desentonase, la mesa fue servida por Margaritas y afiliadas de la Sección Femenina; eso sí, estas últimas en un número algo mayor, como correspondía al equilibrio de fuerzas. El entusiasmo no era tan unánime como la prensa daba a entender: la negativa de Hedilla de aceptar su designación como miembro de la primera Junta Política designada por Franco ponía de manifiesto el descontento de un sector de Falange con el modelo de unificación impuesto, pero también una falta de realismo político en el que no cayeron sus opositores del círculo legitimista (Pilar Primo de Rivera, Aznar y Dávila), muchos de ellos rápidamente elevados a altas responsabilidades que se apresuraron a aceptar. Cuando Franco ordena la detención del santanderino el órgano falangista ourensano, hasta un mes antes ferviente partidario del mismo, guarda absoluto silencio, y cuando firma su destitución de todos los cargos se limita a informar de la noticia en ocho líneas escasas, lo que revela claramente quien mandaba en la nueva FET y de las JONS ${ }^{34}$.

\section{LAS ANTIGUAS MILICIAS Y LA NUEVA FET Y DE LAS JONS}

El decreto de unificación no reservaba para las milicias de RE ni para la JAP siquiera el papel de meras comparsas diferenciadas. A pesar de esto Goicoechea se apresuró a dar a conocer por los micrófonos de Radio Castilla un manifiesto en el que después de reiterar que la fuerza que presidía nunca escatimará sacrificio alguno con las organizaciones hermanas como Falange Española y Requetés, anunciaba su desaparición por mandato de Franco consolándose con lo que ésta tenía de gloriosa porque desaparece Renovación Española cuando ha sido restaurada la bandera de España y su himno ${ }^{35}$. Asimismo, ratificaba que sus milicias se incorporarían sin temor en la organización que surgiese de la fusión. A este res-

una tendencia fusionista anterior (vid. SuÁREZ CoRTINA, M., El fascismo en Asturias (1931-1937), Asturias, Silverio Cañada Editor, 1981, pág. 202).

34 Rumbo, 11-V-1937, pág. 1; en el número del martes día 27 de abril se limitara a informar que el domingo anterior tuviera lugar la primera reunión de la Junta Política de FE y de las JONS con Franco en un «tono de fervor, de eficacia y de altísimo espíritu nacional».

35 Rumbo, 23-IV-1937, pág. 3. 
pecto hay que recordar que los monárquicos ourensanos también dispusieron de un centro de reclutamiento propio con el que contribuyeron, aunque mínimamente, a engrosar el número de voluntarios en el bando franquista. A pesar del enorme predicamento que tenía Calvo Sotelo en la provincia este grupo permaneció en un plano mucho más discreto que sus aliados falangistas, requetés y japistas, con los que no podían competir en la capacidad de movilización.

La impresión es que sus hombres fuertes comprendieron que sus esperanzas estaban en el grupo de generales monárquicos que se alzaron con Franco, y por esto no se propusieron como tarea prioritaria la de organizar una milicia propia para consolidar su parcela de poder. Ciertamente la tarea no habría sido fácil dada la competencia de organizaciones con mucha mayor tradición en este aspecto y el propio elitismo en el que se moviera el partido durante la República; sin embargo, no puede desconocerse el hecho de que influyentes industriales y hombres de negocios militaban en las filas de RE, lo que les hubiese permitido financiar la organización de grupos armados en todo el Estado a imitación de sus compañeros de viaje. En realidad, pensamos que en su decisión pesaba un aspecto mucho más importante: había que insistir en que el mando de la zona franquista fuese exclusivamente militar porque era ahí donde ellos podían ejercer una mayor influencia, y cualquier decisión de consolidar las milicias como entidades controladas por otras fuerzas políticas podría ir en detrimento de ese control que, a priori, les beneficiaba. Por esto, si algún sector se mostraba favorable a la unificación éste era el activo grupo monárquico de tanta influencia en la provincia, y algo parecido sucede con el bloque del catolicismo social: para muchos de sus más egregios representantes la unificación representaba una oportunidad para recuperar parte del terreno perdido como consecuencia de la transformación del golpe militar en guerra civil.

Tampoco podemos olvidar las excelentes relaciones que este sector mantuviera tradicionalmente con Falange y lo enormemente penetrada que esta organización estaba en Ourense por elementos calvosotelistas. Estas conexiones les hacían concebir fundadas esperanzas de que una unificación de las milicias bajo mando militar y con el fiel de la balanza inclinado del lado falangista, les permitiría participar en el reparto de cargos e influencias que se avecinaban o, cuando menos, consolidar su privilegiada posición económica y social. No puede extrañar, por consiguiente, que ya cuando RE anunciara el ocho de marzo de 1937 su propia disolución, reclamando de modo oficial la unificación de todos los partidos -ese «frente patriótico" tan del gusto de Goicoechea- los ourensanos mostrasen su buena disposición que ahora reiterarían, siempre con la ansiada restauración en el ánimo. 
Acción Española, encabezada por su presidente José María Pemán, acabaría también por mostrar su conformidad con los términos esenciales del Decreto. Sus socios ingresaron colectivamente en el nuevo conglomerado por invitación expresa de Franco -tuvieron, por tanto, la misma condición de «militantes» que los de la CT y Falange-, pues, según aquel, tal fusión no era otra cosa que «un reflejo de lo que moral y espiritualmente venía realizándose desde hace cinco años en las páginas de su revista y en los actos culturales de su Sociedad, donde en la formación de unos unánimes pensamientos contrarrevolucionarios colaboraban siempre juntos los hombres de todas las tendencias que ahora se juntan y se estrechan" ${ }^{36}$.

Por lo que respecta a Gil Robles, su posición oficial desde principios de año insistía en que después de la victoria deberán desaparecer los partidos políticos -tengan o no ese nombre -para integrar un solo y amplísimo movimiento nacional. Cuando llegue ese instante venturoso, Acción Popular (...) se enorgullecerá en dar las máximas facilidades (...) ofreciendo incluso el sacrificio de su existencia colectiva cuando la unión sagrada de todos los demás ${ }^{37}$. Este anuncio, prueba evidente del fracaso de las expectativas del salmantino de desempeñar un papel más activo dentro del bando sublevado, provocó reacciones encontradas en las organizaciones locales. La ourensana, tradicionalmente poco activa, no renunció a continuar su labor de proselitismo en aquellas comarcas en las que gozaba de alguna implantación e incluso en otras nuevas. Aunque no nos consta que se discutiese públicamente la claudicación de la dirección, las malas relaciones que su máximo responsable, José Pérez Ávila, mantuvo en todo momento con los cabecillas del golpe militar en la provincia son suficientemente reveladoras de que este proceso no estuvo exento de tensiones.

Los meses anteriores a la publicación del decreto fueron momentos de hondo desconcierto entre los militantes de la organización: la nota de Gil Robles y un discurso de Luciano de la Calzada el 28 de febrero en Zamora suscitaron diversas interpretaciones acerca de si AP dejara o no de existir ${ }^{38}$.

\footnotetext{
36 Rumbo, 16-V-1937, pág. 1.

37 Carta del 17-I-1937 remitida el 3 de febrero a todas las organizaciones regionales y publicada en el Faro de Vigo el 11-1I-1937 (copia original en Biblioteca de la Diputación Provincial de Ourense -BDPO-, Fondo Pérez Ávila).

38 El párrato de la polémica decia textualmente que «Por el bien de España, en representación de nuestro Jefe supremo yo vengo á deciros que desde este momento Acción Popular no es más que una milicia gigantesca; no tenemos ya la apariencia ni la forma de un partido político. Acción Popular no es más que una milicia puesta al servicio del Ejército, cuya primera línea está sujeta al Código de Justicia militar, y los que prestan servicios de custodia en retaguardia, a la Cartilla del Benemérito Instituto" (texto íntegro del discurso enviado a la dirección provincial de Ourense por la Secretaría de Prensa y Propaganda, BDPO, Fondo PA).
} 
Las instrucciones emanadas de Valladolid insistían en que Desaparece como partido político (...), pero subsiste exactamente igual que todos como milicias de primera y segunda línea, siendo, por lo demás, totalmente falso el que la segunda línea tuviese que ingresar en la guardia cívica. Esta situación, las difíciles relaciones entre milicianos y militares a las que ya aludimos y los conflictos que se suscitaban entre ambas instancias por las más diversas cuestiones en no pocos puntos de la provincia, situaron a no pocos militantes en el límite del abandono, a juzgar por la correspondencia mantenida entre los milicianos y su jefe provincial ${ }^{39}$.

La Asamblea Nacional de las JAP, reunida en Burgos el 19 de marzo para adoptar una posición oficial ante los acontecimientos que se avecinaban, aprobó una serie de conclusiones en las que se ratificaba el carácter de milicia de la organización y su completa subordinación al Ejército y al Jefe del Estado; no obstante, se reafirmaba públicamente en los diecinueve puntos de su programa y en el juramento de fidelidad a Gil Robles, en el rechazo de todo intento de reconstrucción de los partidos políticos y en su voluntad de sacrificio, afirmando solemnemente su propósito (y a él supedita su propia existencia) de no ser jamás un obstáculo para lograr la unificación espiritual de España. El hecho de que estas consignas hubieran de repetirse hasta la saciedad por terceras espadas de la organización aún en las vísperas de la unificación prueban, indudablemente, lo poco convincentes que resultaban para los que ostentaban el poder en la España «riacional» y también revelan un hondo error estratégico: a fuerza de repetir su disposición al autoinmolamiento, aquéllos acabaron por convencerse de que no iban a representar un obstáculo serio para sus planes:

«Me interesa aclarar dudas y desvanecer errores, que llevan consigo recelos. Por fortuna para España, una de las primera medidas del Nuevo Estado ha sido la suspensión de los partidos políticos. ¡Por fin se iba ha (sic) hacer obra de conjunto nacional!. Las Juventudes de Acción Popular, que habían visto con dolor como lo que empezó siendo, allá en el año 1931, un amplio movimiento nacional, se rrocó pronto en un partido más, con sus vicios, con sus arribistas, con sus "caciques" electoreros de siempre, en todo momento clavados a la trasera del carro del triunfo. Estas juventudes vírge-

39 El cabo de milicias de la JAP Salvador Carracedo Vallino se quejaba ante la dirección provincial en los siguientes términos: «Trabajamos con toda la fe y continuamente luchando contra los elementos, mojados y enfermos continuamos nuestro servicio y en pago nos dicen que no servimos para nada y que desconfían de nosotros y nos tienen como contrabandistas; esto ya es demás. Te ruego encarecidamente que si esto no marcha en condiciones y se hace justicia (...) procura hacer los medios para que yo pueda marchar al frente y si esto fracasa, en este mes me presento a Tercio» (BDPO, Fondo PA). 
nes, magníficas salieron a la calle y regaron el suelo patrio con su sangre misionera y heroica (...). Estas juventudes (...) vinieron a convertirse, gracias a la orden certera de la Junta de Defensa, en lo que habían soñado siempre y en lo que era su razón de existir: en una Milicia. $Y$ hoy las JAP de España no son más que eso: Milicia al servicio de Dios y de España; ideales que personifica la figura señera y augusta del Generalísimo Franco. Y por si lo expuesto no fuera claro, por si los recelos continuasen, ahí está la conclusión clara, tajante que las "Cruces Negras de la Victoria" acordaron en recientísima Asamblea: La JAP no consentirá jamás QUE LA SANGRE DERRAMADA SIRVA. PARA FLORECER PARTIDOS POLÍTICOS. Por lo que a ella dependa QUEDA DESLIGADA DE TODO AQUELLO PROPIO O AJENO QUE PUEDA SER UN RECUERDO O RENOVACIÓN DE LA VIEJA POLITICA ${ }^{40}$ 》.

Paralelamente, la dirección de las Cruces Negras inicia una desesperada campaña para presentar a la organización como la pionera en la lucha contra el marxismo y en la defensa de la unidad de las milicias con la esperanza, pese a las declaraciones oficiales, de obtener algo más que unas miajas en la hora del reparto. Unas palabras de Hedilla pronunciadas el 16 de febrero en alusión a que fuera Falange la única organización que en las calles de Madrid hiciera acto de presencia al lado del Ejército y de las fuerzas de orden en octubre de 1934 sirven de pretexto para el contraataque: no sólo se afirma que fueron las Juventudes de Acción Popular las que en todo momento llevaron el control y la dirección de toda actuación cívica contrarrevolucionaria y se hace un encendido elogio de las tarifas entonces asumidas, sino que se intenta establecer un claro paralelismo con la situación del momento:

"Ahora como entonces, millares de muchachos de JAP unos como voluntarios en las filas del ejército y de la Legión, otros vestidos con el honroso uniforme de las milicias hermanas donde las circunstancias no han permitido sus propias milicias, luchan, mueren en todos los frentes de batalla en defensa de la paz de España y de la civilización cristiana del mundo ${ }^{41}$.

40 Original mecanografiado y corregido a mano por J. Pérez Ávila del artículo de F. Jiménez de Llano para la Hoja Oficial del Lunes de A Coruña del 5-IV-1937 (BDPO, Fondo PA). Anticipando la tormenta que se le venía encima, concluía afirmando que «Milicia y solo Milicia pronta a desaparecer, si ello fuese necesario, para la obra totalitaria que exige España; y presta siempre en vanguardia y en retaguardia, al abrazo cordial con el hermano, en cuya compañía luchó años ha, en aquella lucha de la calle, y con quien combate ahora, en unión íntima, para arrasar al enemigo común". Vid., asimismo, el n. ${ }^{\circ} 9493$ del Diario Regional (11-111-1937) en el que la Secretaría Nacional de Prensa y Propaganda inserta un largo articulo en el que, entre otras cousas, se recuerda que «La JAP es hoy, exclusiva y únicamente, una milicia; nada queda (...) de aquel amplio movimiento nacional -que sólo fue partido político en la forma externa que el tiempo y las círcunstancias ímponían (...)".

41 Copia mecanografiada encontrada entre los papeles de J. Pérez Ávila (BDPO-Fondo PA). 
Menos de una semana antes de publicarse el decreto, concretamente el día 13, visitaba Ourense el subjefe de las JAP, Ramón Ruiz Alonso. En una alocución pronunciada por la radio se mostró partidario de la creación de un Estado corporativo que hiciese realidad los ideales de Patria, Pan y Justicia, añadiendo que es imprescindible en los actuales momentos una unión completa entre todos, unión sobre todas las cosas: es traidor a España quien se dedique a fomentar la discordia entre las milicias ${ }^{42}$. Inútil intento. En Ourense, como en el resto del Estado, la suerte estaba echada desde mucho tiempo atrás. Anunciada la unificación la JAP va a desaparecer como fuerza y Gil Robles se apresura a mostrar su adhesión por carta a Franco anunciándole que ponía en sus manos "toda la organización, tanto el partido, absolutamente en suspenso, como las milicias ya organizadas militarmente para que adopte las medidas que estime convenientes en orden a esa deseada unificación". Paralelamente daba instrucciones a Luciano de la Calzada para que se presentase en Cuartel General «a recibir órdenes, ya sea la disolución, la fusión obligatoria con otro u otros organismos, o la incorporación pura y simple al Ejército" ${ }^{43}$. El jefe nacional de la JAP remitió un telegrama en nombre de la Junta de Mando en el que le reiteraba su incondicional adhesión «en este momento en que culmina una historia de sacrificios para España (...) porque sabemos que una Patria se hace con dolor y renunciación, con el ánimo sereno y el corazón muy alto» ${ }^{44}$. En Ourense el comité provincial de AP enviaba el día veintitrés un telegrama a Franco en el que le anunciaba la disolución de todas las organizaciones del partido en la provincia, «acatando y cumpliendo gustosos el Decreto de Vuecencia y se honra al testimoniar en nombre de todos su inquebrantable adhesión al Jefe del Estado, esperando la orden que los movilice, nunca para discutirla y siempre para obedecerla» ${ }^{45}$.

Para los japistas, sin embargo, se abría un período de desconcierto que hacía pensar que sus mandos se resistían tercamente a aceptar los hechos consumados. Casi un mes después de promulgarse el Decreto, el 17 de mayo, Pérez Ávila escribía al general jefe de la VIII División, Antonio Aranda, quejándose amargamente de la actitud del comandante militar de la provincia, que no sólo se negaba a autorizar una reunión de sus milicias de Viana do Bolo y O Barco de Valdeorras sino que ni se dignaba a recibirlo. La lacónica respuesta de Aranda no dejaba lugar a dudas sobre la

\footnotetext{
42 La Región, 14-IV-1937, pág. 2.

43 Reproducida en Rumbo, 24-IV-1937, pág. 1.

44 Rumbo, 22-IV-1937, pág. 1.

45 La Región, 24-IV-1937, pág. 3
} 
suerte de la JAP: después de lamentar la conducta de Soto, añadía que Aparte de esta circunstancia de forma debo decirle que en el fondo no cabe ya en vista de las instrucciones recibidas del Generalísimo autorizar reuniones de partidos o simpatizantes de otras organizaciones que las de Falange Española Tradicionalista de la JONS a las cuales deben incorporarse cuantos quieren actuar en dicho Movimiento Nacional ${ }^{46}$.

La actitud de los carlistas ourensanos es más difícil de seguir por la ausencia de un órgano de prensa y la inexistencia de archivos privados que permitan conocer la impresión real de sus mandos fuera de las declaraciones oficiales. Éstas hicieron patente una vez más la división existente en sus filas: el pretendiente carlista y Fal Conde respondieron con un elocuente silencio; en adelante la estrategia de este último pasaría por acatar de hecho la unificación mientras trataba de no perder totalmente el control sobre la CT esperando que los tiempos fuesen más propicios para restablecer su autoridad y la del regente. El sector navarro reiteró, como ya hiciera el día dieciséis, su casi unánime conformidad y de eso fue de lo que se hicieron eco los medios de prensa; para ellos, cómodamente instalados en sus cargos, el tiempo parecía su mejor aliado, ya que les permitía trabajar en la nueva organización a favor de la organización de una futura restauración en la persona del primogénito de Alfonso XIII convertido al tradicionalismo. Por su parte, la Junta Nacional Carlista de Guerra remitía un telegrama a Franco en el que reiteraba su «cordial, sincera y desinteresada adhesión, ansiosos contribuir servicio de Dios, salvación de Espaî́a y recuperación de sus destinos con triunfo principios secularmente defendidos por el Tradicionalismo en inquebrantable unión espiritual de todos los españoles ${ }^{47}$.

Era preciso leer entre líneas para descubrir las discrepancias: el comentario editorial de Rumbo del día veintidós seguía insistiendo en la tesis de que ninguna milicia quedaba disuelta, sino que todas quedaban fundidas en una sola, y al tiempo advertía que «Sólo un malvado o un intransigente miope puede aún poner sombras al gran decreto constitutivo del Estado integral. No puede haber, de hoy en adelante, categorías de españoles: vencedores y vencidos». Más explícitos resultaban los informes policiales, a través de los cuales puede colegirse que en la provincia no todo fueron unanimidades ${ }^{48}$. Además, los tradicionalistas se quejaron amarga-

46 BDPO, Fondo PA.

47 Rumbo, 22-IV-1937, pág. 1.

48 Según un documento de la Comisaría de Investigación y Vigilancia, el histórico tradicionalista Carlos Manuel Gómez García, más conocido por Vedmar, «(...) a su llegada al pueblo de su 
mente de que en Ourense ellos fueron los más perjudicados por el Decreto de Unificación. En particular su organización juvenil, los Pelayos, fue absorbida por Falange y la considerada mejor banda de Cornetas y Tambores de España-después de la de Fal Conde de Andalucía- desapareció en los locales falangistas ${ }^{49}$. En realidad esto era una mera anécdota que pone de manifiesto las notables dificultades para integrar las respectivas secciones juveniles. Además, los carlistas consiguieron la satisfacción de ver elevado el catolicismo a la categoría de religión oficial del Estado, prohibiendo cualquier otra actividad proselitista y borrando todo rastro de laicismo en ámbitos tan queridos para los ourensanos como el de la enseñanza. $Y$, sobre todo, ellos fueron inicialmente los principales beneficiarios de ese pacto conseguido en el ámbito estatal de reparto de los máximos cargos de la nueva formación. Como es conocido, parece ser que las bases de éste, en la mayoría de las provincias, pasaban por entregarle la jefatura a un falangista y la secretaría a un carlista, reconociendo así el mayor peso de los primeros en la guerra, excepto en Navarra, Logroño y País Vasco, donde la situación fue justamente la inversa ${ }^{50}$.

Sin embargo, en Ourense, el 19 de mayo se confirmaba definitivamente que el cargo de jefe provincial de FET y de las JONS correspondería a un carlista, Daniel Romero Álvarez, miembro de su Junta de Guerra, mientras que el secretariado provincial recaía en el camisa vieja Eduardo Valencia Fernánde ${ }^{51}$. No resulta fácil explicar los porqués de esta decisión teniendo en cuenta el muy superior peso de los falangistas dentro de la provincia. A modo de hipótesis es posible que se premiase de esta forma el hecho de que fuesen los tradicionalistas los que llevasen el peso de los contactos con los mandos militares antes de la sublevación, sin olvidar que Meleiro, por

naturaleza [Xinzo de Limia], fue nombrado Secretario de FET y de las JONS, de cuyo cargo fue destituido por inepto (...). No obstante lo antedicho se le volvió a dar dentro de dicha Organización el cargo de Delegado de Información e Investigación (...) [y] fue además un indisciplinado dentro de la Organización, ya que demostró ser en todo contrario a la unificación de Falangistas y requetés así como también al uso de la camisa azul (...) [por lo que] el hoy Jefe Local de Falange en dicha Villa, se vió (sic) precisado de dar cuenta de él a la Superioridad, por su insubordinación (...)" (Vid. ACO, expediente 101.401).

49 Rego Nieto, M., El carlismo orensano. 1936-1980, Vigo, ed. del autor, 1985, pág. 16.

50 Por el contrario, en Cataluña, este modelo acabaría quebrando, ya que a mediados de marzo los dirigentes de la antigua FE de las JONS maniobraron para dejar sin efecto el pacto emprendiendo una campaña de desprestigio contra los carlistas para conseguir, finalmente que la nueva FET fuese simplemente el resultado de la transformación de FE de las JONS (vid. THOMAS, J. M. ${ }^{a}$, «Las falanges de Barcelona entre 1934 y 1940", en Historia y Fuente oral, n. ${ }^{\circ}$, Barcelona, 1992, págs. 106)

51 Nombramiento firmado por el secretario de la Junta Política de FET y de las JONS, el capitán de Ingenieros Ladislao López Bassa, el 19 de mayo de 1937 (vid., asimismo, Rumbo, 10-VI1937, pág. 1). 
aquel entonces de nuevo encumbrado a la jefatura provincial, no despertaba una total unanimidad entre los mandos militares de la provincia. La designación para el secretariado de Valencia no sólo era un reconocimiento para el fundador del núcleo falangista ourensano y primer jefe provincial, sino también una revancha, si acaso algo más que simbólica, frente a Meleiro, que precisamente lo desplazara de esta jefatura dos años y medio antes. Por el contrario, Romero, en su condición de comisario de guerra, puesto en el que sustituiría a Bautista Pérez de Cabo, debió estar presente en la reunión en Burgos del Consejo de la Tradición del 22 de marzo de 1937 en la que los asistentes mostraran una clara voluntad de colaboración -más bien de subordinación- con Franco y no descartaran una futura unión con Falange en la línea de Rodezno; era, claramente, un hombre menos comprometido que el falangista, y, por esto, más adecuado para los nuevos tiempos. De todas formas sólo fue una situación transitoria, y pronto el baile de cargos no olvidaría retribuir generosamente a los camisas viejas.

Tampoco en el más alto nivel jerárquico de la organización las cosas fueron mal para los falangistas. Más de dos tercios de los jefes provinciales efectivamente nombrados procedían de FE de las JONS, el primer secretario general de la organización fue Raimundo Fernández Cuesta -que ocupara el mismo cargo en ésta última- y casi el doble de los consejeros que asistieron al I Consejo Nacional lucieran camisa azul ${ }^{52}$. Cosa bien diferente era el Gobierno del Estado. Cuando en enero de 1938 Franco nombre a su primer gabinete, unos y otros comprenderán que los equilibrios de poder dentro del conglomerado que conforma el bando «nacional» son mucho más complejos que dentro del partido y ahí las alianzas no sólo se forjan a dos bandas, sino que es preciso integrar, además, a militares y alfonsinos en un juego en el que Franco dará pruebas de ser un consumado experto a lo largo de toda su dictadura.

En principio, la refundición de las milicias no significó una desmovilización de sus efectivos, agrupados ahora bajo el común denominador de Milicia Nacional. Las de primera línea destinadas en los frentes pasaron a agruparse en Banderas, aunque el reclutamiento de nuevos efectivos continuó realizándose momentáneamente por los responsables de cada unidad. Las de segunda línea se situaban bajo la estricta dependencia del delegado de Orden Público y del jefe regional de milicias, quedando sus funciones limitadas a los servicios estrictamente precisos para auxiliar los propios de la Guardia civil, Asalto y Seguridad. Asimismo, se congelaba la

52 ThомÀs, J. M.a , Lo que fue la Falange..., op. cit., págs. 232-233. 
incorporación de nuevos efectivos hasta que no quedase establecido el número definitivo de éstos ${ }^{53}$. Se abría entonces un período de transición durante el que las diferentes milicias que operaban en Ourense van a seguir funcionando de forma autónoma. Y esto a pesar de la orden del 30 de abril de 1937, que pretendía favorecer la integración disponiendo una representación equitativa de carlistas y falangistas en el comité de unificación provincial. También mantuvieron inicialmente sus respectivos alojamientos en las diferentes localidades en las que existían dos locales separados, aunque la orden del 8 de junio vino a eliminar este símbolo de clara división al establecer que en las poblaciones de menos de diez mil habitantes ambas compartiesen el mismo cuartel. Lo mismo sucedió con el uniforme, el saludo y los distintivos propios a la espera de que la superioridad clarificase estos extremos.

Precisamente éste será el último caballo de batalla de los dirigentes de las milicias que se consideraban perjudicadas por la unificación-absorción. Los falangistas no deseaban que las demás milicias, muy especialmente las JAP, continuasen haciendo uso de sus emblemas, mientras éstos, profundamente desmoralizados, hacían con frecuencia caso omiso de las diferentes disposiciones al efecto a la hora de lucirlos. Aún el cuatro de junio el secretario provincial de FET y de las JONS, Fernando Valencia, recordaba un oficio remitido a los respectivos jefes de milicias la obligación de usar a diario las prendas de vestir del uniforme de sus milicias respectivas en tanto no se hace público el uniforme único de integración. La polémica obligó al comandante provincial a dirigirse en reiteradas ocasiones al general Aranda para que se pronunciase sobre la cuestión, resolviendo el propio Franco que hasta que no se publicase la disposición complementaria del Decreto 255 las diferentes milicias que operaban en el ámbito jurisdiccional de la VIII División Orgánica, podrían seguir usando los signos exteriores característicos y peculiares de cada una ${ }^{54}$. En cuanto al saludo recíproco entre milicianos y entre éstos y militares, que seguia siendo una fuente inagotable de conflictos, se mantuvo una cierta indefinición hasta el 28 de junio en que el Cuaitel General dispuso que entre milicianos y oficiales y entre oficiales con destino en las milicias debería regir el característico saludo brazo en alto, optando por dejar actuar a su libre albedrío a los oficiales de milicias y del Ejército.

53 Telegrama dirigido por el teniente coronel de Milicias Armadas de la VIII División el 2 de mayo de 1937 al jefe provincial de milicias de Ourense.

54 Resolución del Cuartel General del Generalísimo comunicada por telegrama a Antonio Aranda el 6 de junio de 1937 y remitida a la Delegación e Inspección Provincial de Milicias por el teniente coronel jefe de la Milicia Nacional del VIll Cuerpo del Ejército cinco días más tarde. 
No será hasta julio de 1937 cuando la tan cacareada unificación de las milicias se haga realmente efectiva en Ourense. El día cuatro de ese mes se abrió el plazo para la admisión de nuevos afiliados a FET y de las JONS; veinticuatro horas más tarde el gobernador militar recibe un telegrama en el que se le ordena hacer efectiva la disolución de todas las agrupaciones armadas actuantes en la provincia, disponiendo que sus componentes se sumarán, si lo desean, a la Milicia Nacional de FET y de las JONS para su unificación y refundición en ella; a este efecto habrán de solicitarlo del Jefe Militar de la Milicia Nacional de su provincia. Al día siguiente el entonces capitán inspector provincial de milicias, Luis Fernández-España, comunicaba al jefe provincial de las JAP y a los restantes responsables de Milicias la mencionada disposición y, veinticuatro horas más tarde, ordenaba comparecer a todos los milicianos de primera línea a las diecisiete horas del jueves día ocho en el cuartel de la nueva Milicia Nacional, situado en la antigua Casa del Pueblo, para proceder a su reorganización. Tres horas más tarde, en el cuartel del disuelto Batallón de Caballeros de Santiago, debían hacerlo los de segunda línea, que en este mismo momento quedaron encuadrados en un batallón mandado accidentalmente por el capitán de Infantería Eduardo Saavedra Caballé y con los oficiales del Ejército Srs. Piñeiro, Franqueira, Seijo, Vicente y Estévez ${ }^{55}$. En el acto de despedida el capitán jefe provincial de la Milicia Nacional recordó los motivos de fondo de la disolución, al tiempo que lanzaba un aviso para navegantes:

«Por S. E. el Generalísimo, se ha dispuesto la disolución de todas las agrupaciones armadas de diversas clases que venían actuando como Milicias, al objeto de que todas ellas sean refundidas en la Milicia Nacional de FET. El espíritu de esta orden es sin duda alguna, con el objeto de reforzar cada vez más la unidad nacional, suprimiendo medios que con la existencia de tantas organizaciones pudieran influir posiblemente en el ánimo de algunos componentes, llevando su pensamiento por derroteros equivocados. (...) Por todo ello espero y creo firmemente que todos sabrán cumplir con el deber patriótico que no está impuesto (...) sin que haya necesidad de emplear medidas coactivas para ello y bajo la disciplina militar a que nos sometemos, medio que nos conducirá a la victoria (...) ${ }^{56}$.

E : un último acto de simbólica protesta, Pérez Ávila, que ya se negara a cu nplir cualquier orden verbal al respecto, informaba respetuosamente al mando militar de la imposibilidad material para dar cumplimiento al men-

55 La orden afectaba únicamente a las milicias de la capital; para las organizaciones existentes fuera de ésta se quedaba a la espera de las «instrucciones correspondientes».

56 Rumbo, 10-VI1-1937, pág. 2. 
cionado oficio ya que a las 21 horas del mismo día de ayer [6 de julio] (...) ha sido leído [su oficio] con todo detenimiento en voz alta por un miembro de esta ex-Junta de mando, declarándose por lo tanto disuelta la milicia de la $J A P^{57}$. Sería éste el penúltimo oficio que el dirigente japista recibiría en calidad de tal; el día 10 se le ordenaba entregar en el Cuartel de los Caballeros de Santiago una relación nominal del personal afiliado a la segunda línea entre los veintinueve y los cincuenta años para seguir prestando los servicios de la Plaza.

La rígida censura militar y los apologistas del Caudillo silenciaron, también en Ourense, el descontento que la unificación provocó en determinados círculos del antiguo catolicismo social. A través de la correspondencia privada de Pérez Ávila con Luciano de la Calzada y Gil Robles sabemos que ninguno de los milicianos de 1. ${ }^{a}$ línea de las JAP se incorporó, por lo menos inicialmente, a la Milicia Nacional; con respecto a la 2. a línea, las cartas del ourensano permiten adivinar su desacuerdo con todo el proceso de unificación, quejándose del doble lenguaje de los militares: mientras los oficios remitidos a la jefatura hablaban de que sus afiliados quedarían en libertad para incorporarse o no a la nueva organización la realidad fue que todos ellos quedaron incluidos en esta Milicia Nacional de FET y de las JONS. 2. ${ }^{a}$ línea sin solicitarlo. (...) Sin comentarios. Éstos os los podréis imaginar (...) ahora vosotros tenéis la palabra. La respuesta de Gil Robles no fue otra que la de la aceptación resignada de la imposición aunque para nosotros haya sido lógicamente dolorosa, nos queda la satisfacción de que al acatar leal y disciplinadamente las disposiciones del Jefe del Estado, hemos prestado a España el último sacrificio que como colectividad nos era pedido ${ }^{58}$. De todas formas, los antiguos japistas no tardaron en pasar por la Secretaría Provincial de la organización, situada en el $n .^{\circ} 7,2 .^{\circ}$ de la calle de Lamas Carvajal, para recoger los impresos para formalizar su inscripción.

Pero ni aún así desaparecerían los motivos de tensión. Los milicianos voluntarios de la JAP llevaban tiempo solicitando permiso para incorporarse a filas en bloque como unidad diferencia o, cuando menos, para reforzar alguno de los contingentes que operaban en el frente de Madrid. Cuando el comandante militar los autorizó finalmente para partir tomó la decisión -parece que personal y diferente a la que era norma con las otras milicias- de destinarlos a Grana en lugar de Villacastín, como estaba pre-

57 Copia manuscrita del oficio remitido a Luis Espada por el jefe provincial de la JAP (BDPO, Fondo PA).

58 Respuesta de Gil Robles a los informes remitidos por J. Pérez Ávila desde Lisboa el 21-VII1937 (BDPO-Fondo PA) 
visto por Pérez Ávila. Este hecho provocó un serio inicidente que acabó en el arresto de su exresponsable provincial, cuya versión no deja lugar a dudas sobre sus malas relaciones con Soto y de lo claro que tenía éste quién mandaba realmente en las milicias unificadas:

"Comandante: La JAP ya no existe, todo son unos.

Yo: No existe pero colea porque por una temporada tiene que colear forzosamente.

Comandante: Yo me encargaré que deje de colear, y después de todo tú quien eres para venirme a mi con eso, ¿qué cargo tienes tú ahora?.

Yo: El de Jefe provincial que fue de la JAP y hoy un miliciano de FET y de las JONS.

Comandante: Buenos hemos terminado (...) estás arrestado en el cuartel

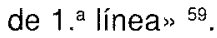

En adelante, el menor indicio de discrepancia sería interpretado como inequívoco síntoma de estar poseído por el virus masónico-marxista secundado por el multiforme caciquismo en confuso maridaje. Véase lo que afirmaba al respecto un articulista de Rumbo:

«(...) todavía quedan algunos de aquellos traidores (...) que ahora que les es imposible obstaculizar cara a cara las rutas del Imperio, se esfuerzan por demostrar una satisfacción que están muy lejos de sentir; y a las manifestaciones de entusiasmo y alegría exteriorizadas por todos los buenos españoles (...) corresponden con unas sonrisitas y aplausos que delatan el poco entusiasmo de sus corazones. Se ve claramente la mano oculta de los miembros disgregados de las logias de Amsterdam, de la Gran Logia Revolucionaria y marxista importada de Moscú (...) Pero estos son secundados, aunque no directamente y de común acuerdo, por el caciquismo, plaga de la ciudad y del campo, por esos logreros y acaparadores de las rastrerías de la vieja política» ${ }^{60}$.

En realidad, las numerosas noticias de pequeños enfrentamientos e intromisiones de notables locales en la nueva milicia de que tenemos noticia en diferentes puntos de la provincia evidencia que algunas de las causas que se utilizaron como pretexto de la unificación se mantuvieron vivas con el paso de los meses. Sin embargo, la ausencia de una oposición mínimamente articulada como resultado de la situación y los equilibrios internos en cada uno de los actores en juego permitió al Ejército, también en Ourense, solventar sin mayores problemas lo que hubiera podido convertirse en un problema político de primer orden.

59 BDPO, Fondo PA.

60 Rumbo, 24-IV-1937, pág. 3. 